\title{
Figurative Language in the Song Lyrics of 5 Seconds of Summerand One Direction's Albums
}

\author{
Ni Putu Dina Sinjiardita ${ }^{1^{*}}$, I Ketut Tika ${ }^{2}$ \\ ${ }^{[12]}$ English Department, Faculty of Arts, Udayana University \\ ${ }^{1}$ [dinasinji@gmail.com], 2[ketut_tike@yahoo.com] \\ *Corresponding Author
}

\begin{abstract}
This study is entitled Figurative Language in The Song Lyrics of 5 Seconds of Summer and One Direction's Albums. This study is aimed to identify figurative language and explain the meaning of those types of figurative language found in the song lyrics of 5 Seconds of Summer's album entitled "Sounds Good Feels Good" and One Direction's album entitled "Midnight Memories". The data were collected using the documentation research method. After the required data were collected, they were analyzed using qualitative method. The analysis of the data were presented in a descriptive way to give clear explanation. The findings show that in 5 Seconds of Summer's album five types of figurative language found in the data; they are: personification, irony, simile, metaphor and hyperbole. While from One Direction's album four types of figurative language were found; they are: personification, simile, metaphor and hyperbole. There were two types of meaning found in the data; they are: conceptual meaning and connotative meaning. It can be concluded that in the rock band's album Sounds Good Feels Good irony was found; however, in pop band's album Midnight Memories irony was not found. Both in those two albums conceptual meaning was more frequently used.

Keywords: Figurative Language, Meaning, Personification, Irony, Simile, Metaphor, Hyperbole

Abstrak

Penenelitian ini berjudul Figurative Language in The Song Lyrics of 5 Seconds of Summer and One Direction's Albums. Tujuan dari penelitian ini adalah untuk mengidentifikasi figurative language dan menjelaskan arti dari tipe-tipe figurative language yang ditemukan pada lirik lagu dari album 5 Seconds of Summer yang berjudul "Sounds Good Feels Good" dan dari album One Direction yang berjudul "Midnight Memories". Data untuk penelitian ini dikumpulkan menggunakan metode dokumentasi. Setelah data yang diperlukan terkumpul, data tersebut kemudian dianalisa menggunakan metode kualitatif. Untuk memberikan penjelasan yang jelas data yang telah dianalisa ditampilkan secara deskripsi. Temuan dalam penelitian ini menunjukkan bahwa pada album 5 Seconds of Summer ditemukan lima tipe figurative language, seperti: personifikasi, ironi, kiasan, metafora dan hiperbola. Sedangkan pada album One Direction ditemukan empat tipe figurative language, yaitu: personifikasi, kiasan, metafora dan hiperbola. Terdapat dua tipe makna yang digunakan pada kedua album tersebut, yaitu: makna konseptual dan makna konotatif. Dapat disimpulkan bahwa pada album band rock Sounds Good Feels Good ditemukan lirik yang mengandung ironi, sedangkan pada album band pop Midnight Memories lirik yang mengandung ironi tidak ditemukan. Makna konseptual lebih sering digunakan pada kedua album tersebut.
\end{abstract}

Kata kunci: figurative language, pengertian, personifikasi, ironi, kiasan, metafora, hiperbola 


\section{Background}

A subfield of linguistics developed in the late 1970s is pragmatics which studies how people comprehend and produce a communicative act or speech act in a concrete speech situation which is usually a conversation. It distinguishes two intents or meanings in each utterance or communicative act of verbal communication. One is the informative intent or the sentence meaning, and the other is the communicative intent or the speaker's meaning (Leech, 1983; Sperber and Wilson, 1986). The ability to comprehend and produce a communicative act is referred to as pragmatic competence (Kasper, 1997) which often includes one's knowledge about the social distance, social status between the speakers involved, the cultural knowledge such as politeness, and the linguistic knowledge explicit and implicit.

Figurative language is a language that contains figures of speech, such as metaphor, simile, personification and hyperbole, etc. namely expression that make comparisons or associations which are meant to be interpreted imaginatively rather than literally (Morner and Rausch - 1991:83). According to Knickerbocker \& Reninger (1963), figurative language is sometimes called metaphorical language, or simply metaphor, because its Greek ancestor "Metaphereien" means to carry meaning beyond its literal meaning. Keraf (2004:129) states that figure of speech is a deviation of a language from the common language, whether in spelling, word construction (sentence, clause and phrase) or application of a language term.

Figurative language is very common in poetry, but it is also used in prose, nonfiction writing and song lyrics as well. There are some similarities between poetry and song; they are: rhythm, figurative expression and emotion. Songs themselves have to be rhythmetic so do poetry. In fact, there is even a form of poetry which is made into song called lyrical poems. Sometimes they are used in songs, sometimes left as just words with a specific rhythm. All-inall, song is poetry. The difference between them is so small that all poetry needs is either a vocalist or instruments.

We can find figurative language in song lyric just like in poetry. According to Merriam-Webster, song is the act or art of singing, a poetical composition and a poem easily set to music. Song is important for people around the world. A lot of people like to listen to music or song. They listen to sing when they are sad, happy, bored or maybe when they have a lot of tasks or things to do. Song is interesting entertainment that is very common in society.

Based on the explanation above the figurative language in the song lyrics of 5 Seconds of Summer and One Direction are interesting to be explored in a study entitled "Figurative Language in The Song Lyrics of 5 Seconds of Summer and One Direction's Albums." The reason why their albums was chosen was that their albums are the most albums from 5 Seconds of Summer and One Direction that contain a lot of figurative language compared to their other albums.

\section{Problems of the Study}

a) What types of figurative language are found in the song lyrics of 5 Seconds of Summer and One Direction's albums?

b) What are the meanings of each figurative language found in the song lyrics of 5 Seconds of Summer and One Direction's albums? 


\section{Aims of the Study}

a) To find types of figurative language in the song lyrics of 5 Seconds of Summer and One Direction's albums.

b) To identify the meaning of each figurative language found in the song lyrics of 5 Seconds of Summer and One Direction's albums.

\section{Research Method}

In making a scientific writing, methodology plays an important role to be followed. In obtaining the data, the research method covers four points: data source, method and technique of collecting data, method and technique of analyzing data and method and technique of presenting analysis.

\subsection{Data source}

In this study, the data were taken from 5 Seconds of Summer and One Direction's albums. 5 Seconds of Summer is an Australian rock band from Sydney established in 2011. The group were originally YouTube celebrities, posting videos of themselves covering songs from various artists during 2011 and early 2012. While One Direction (commonly abbreviated as 1D) are an English-Irish pop boy band based in London. The group signed with Simon Cowell's record label Syco Records after forming and finishing third in the seventh series of the British televised singing competition The X Factor in 2010. In this study two albums were used as the data source, they are Sounds Good Feels Good from 5 Seconds of Summer and Midnight Memories from One Direction. There were fifteen song lyrics taken from those albums as the primary data. Eight song lyrics were taken from Sounds Good Feels Good by 5 Seconds of Summer, while from Midnight Memories by One Direction seven song lyrics were taken.

All the data were taken from the website www.azlyrics.com. The song lyrics were searched on the website one by one to attach them to the appendix. The data were chosen because the song lyrics of 5 Seconds of Summer and One Direction contain strong meanings that are concerned with the topic of this study.

\subsection{Method and technique of collecting data}

The data were collected using documentation research method. In order to get the data, all the song lyrics of 5 Seconds of Summer and One Direction's albums were read to choose the songs which have figurative language in the lyrics. All the lyrics of the chosen songs were then downloaded. The next step was listening to the songs and reading the song lyrics carefully. By using note taking technique, the sentences containing figurative language were noted down and then the best ones were chosen to be analyzed according to the theory.

\subsection{Method and Technique of Analyzing Data.}

After the required data were collected, they were analyzed using qualitative method. Based on the theory of figurative language proposed by Knickerbocker and Reninger (1963:367), and the theory about various types meaning proposed by Leech (1974:64). The technique of analyzing data involved the following stages: 1 . Describing each theme and understanding the feeling of the song lyrics, 2. Identifying the key words to classify the type of figurative language found in the song lyrics, 3. Analyzing each type of figurative language and the meaning found in the 
song lyrics based on the theory used in this writing.

\subsection{Method and Technique of Presenting Data}

The analysis of the data were presented in a descriptive way to give a clear explanation. All of the data were analyzed using the theory of figurative language proposed by Knickerbocker and Reninger (1963) and theory of meaning proposed by Leech (1974). The first analysis presented types of figurative language found in the songs lyric of 5 Seconds of Summer's album "Sounds Good Feels Good" and One Direction's album "Midnight Memories", after that the meaning of each type of figurative language found in the songs lyric of 5 Seconds of Summer's album "Sounds Good Feels Good" and One Direction's album "Midnight Memories" was presented The data were presented by making a description about the kinds of figurative language found in the songs lyric of 5 Seconds of Summer's albums "Sounds Good Feels Good" and One Direction's album "Midnight Memories."

\section{Result and discussion}

Here are the analyses of the data and their meanings found in the song lyrics of 5 Seconds of Summer's album "Sounds Good Feels Good" and One Direction's album "Midnight Memories".

\subsection{Analysis of Personification and Its Conceptual Meaning}

(Verse: 2)

I can't sleep 'cause my mind keeps racing (1)

My chest hurts 'cause my heart keeps breaking

I'm so numb and I can't stop shaking

And we all fall down
The sentence in verse: 2 , line: 1 is a personification. The word 'mind' according to Oxford Advanced Learner's Dictionary is the element of a person that enables them to be aware of the world and their experiences, to think, and to feel; the faculty of consciousness and thought. While the word 'racing' in the sentence above can be denoted as moving swiftly.

The sentence 'I can't sleep 'cause my mind keeps racing' is a personification according to the theory of figurative language proposed by Knickerbocker and Reninger (1963). The word 'racing' can only be associated with human-being, while in the sentence above the word 'mind' is non-human thing; however, it is treated like a human being. As described above, 'mind' is the element of a person that is considered as an abstract idea. Hence, it is clear that the sentence 'I can't sleep 'causes my mind to keep racing' is personification.

Based on the theory of meaning proposed by Leech (1974), the sentence 'I can't sleep 'cause my mind keeps racing' is a kind of conceptual meaning. All of the meanings are already described in the sentence, or in other words, the sentence does not refer to any other meaning. The listener of the song can easily understood the lyrics of the song since all the words in the sentence can be taken literally. In this case, the writer of the song lyrics wants to tell the listener that he or she cannot sleep because he or she is thinking about a lot of things.

\subsection{Analysis of Irony and Its Connotative Meaning}

(Verse: 1)

Everybody's got their demons

Even wide awake or dreaming

I'm the one who ends up leaving 
Make it okay

The sentence in verse: 1 , line: 1 is an irony. The word 'demons' in the sentence above according to Oxford Advanced Learner's Dictionary is evil spirit or devil, especially one thought to possess a person or act as a tormentor in hell.

The sentence 'everybody's got their demons' according to the theory of figurative language proposed by Knickerbocker and Reninger (1963) is an irony. The word 'demons' in the sentence above literally is not an evil spirit or devil. In this case, the word 'demons' refers to 'anger.' The writer of the song lyrics wants to give an ironic sense to the sentence by using the word 'demons' to describe 'anger' in the sentence. Hence, it is clear that the sentence 'everybody's got their demons' is irony.

Based on the theory of meaning proposed by Leech (1974), the sentence 'everybody's got their demons' is kind of connotative meaning. The sentence cannot be interpreted lexically and literally. It must be interpreted according to the situation. The meaning of the word 'demons' in the sentence above can be analyzed into two separated concepts called denotative and connotative meanings. The sentence 'everybody's got their demons' connotes that everybody certainly has an anger side of themselves. Sometimes people will be angry with something or someone for some reasons.

\subsection{Analysis of Simile and Its Conceptual Meaning}

(Verse: 9)

And I been waiting for this time to come around

But, baby, running after you

Is like chasing the clouds
The sentence in verse: 9 , line: 2 and 3 is a simile. The word 'clouds' according to Oxford Advanced Learner's Dictionary is a visible mass of condensed watery vapor floating in the atmosphere, typically high above the general level of the ground.

According to the theory of figurative language proposed by Knickerbocker and Reninger (1963), the sentence 'but, baby, running after you is like chasing the clouds' is a simile. The word 'like' in the sentence has a function to compare 'you' with 'clouds.' It shows the similarity between 'you' and 'clouds', even though they are totally different things. The writer of the song lyrics wants to describe that chasing his partner is as hard as chasing the clouds that keep moving in the sky and so far away from the ground. Hence, it is clear that the sentence 'but, baby, running after you is like chasing the clouds' is simile.

Based on the theory of meaning proposed by Leech (1974), the sentence 'but, baby, running after you is like chasing the clouds' is a kind of conceptual meaning. The sentence does not refer to any other meaning. The listener of the song can easily understand the meaning of the lyrics. In this case, the writer of the song lyrics wants to describe that it is so hard to become closer with his partner, because whenever he tried to come closer his partner she keeps moving away to avoiding him. It is the same like when people tried to chase the clouds that keep moving in the sky and so far away from their reach. Therefore, the writer thinks that his partner is unreachable like the clouds.

\subsection{Analysis of Hyperbole and Its Connotative Meaning}

(Verse: 2)

Diana, let me be the one to

Light a fire inside those eyes 
You've been lonely, you don't even know me

But I can feel you crying

Diana, let me be the one to

Lift your heart up and save your life

I don't think you even realize

Baby, you'd be saving mine, Diana

The sentence in verse: 2 , line: 2 is a hyperbole. The word 'fire' according to Oxford Advanced Learner's Dictionary is a process in which substances combine chemically with oxygen from the air and typically give out bright light, heat and smoke; combustion or burning. While the word 'eyes' is each of a pair of globular organs of sight in the head of humans and vertebrate animals.

According to the theory of figurative language proposed by Knickerbocker and Reninger (1963), the sentence 'light a fire inside those eyes' is a hyperbole. It seems that the sentence is exaggerated. It is impossible to light a fire inside someone's eyes. Hence, it is clear that the sentence 'light a fire inside those eyes' is a hyperbole.

Based on the theory of meaning proposed by Leech (1974), the sentence 'light a fire inside those eyes' is a kind of connotative meaning. The sentence above cannot be interpreted lexically and literally. It should be interpreted according to the situation. The meaning of the word 'fire' from the song lyrics can be analyzed into two separate concepts called denotative and connotative meaning. In this case, the word 'fire' refers to happiness. The sentence 'light a fire inside those eyes' connotes that the writer wants to be the one who brings happiness to the person he was talking about in the song, by making that person happy; therefore, that person will not be crying anymore.

\subsection{Analysis of Metaphor and Its Conceptual Meaning}

(Verse: 3)

Only half a blue sky, kinda there but not quite

I'm walking around with just one shoe, I'm half a heart without you

I'm half a man at best with half an arrow in my chest

I miss everything we do, I'm half a heart without you

The sentence in verse: 3 , line: 2 is a metaphor. The word 'heart' according to Oxford Advanced Learner's Dictionary is a hollow muscular organ that pumps the blood through the circulatory system by rhythmic contraction and dilation. In vertebrates there may be up to four chambers, with two atria and two ventricles.

According to the theory of figurative language proposed by Knickerbocker and Reninger (1963), the sentence 'I'm half a heart without you' is a metaphor. The writer of the song lyrics comparing two different things became similar without using the word 'like' or 'as.' In this case, the writer comparing 'I' with 'heart.' The writer wants to describe that without the person he was talking about in the lyrics he is like half a heart or in the other hand means his life is not complete without her. Hence, it is clear that the sentence 'I'm half a heart without you' is a metaphor.

Based on the theory of meaning proposed by Leech (1974), the sentence 'I'm half a heart without you' is a kind of conceptual meaning. All of the meanings are already described in the sentence, or in other words, the sentence does not refer to any other meaning. The listener of the song can easily understand the 
lyrics of the song since all the words in the sentence can be taken literally. In this case, the writer wants to describe that his life is not complete without her in his life. Therefore, he needs her in his life to make his life complete.

\section{Conclusion}

This study has described and analyzed the figurative language found in the song lyrics of 5 Seconds of Summer's album entitled Sounds Good Feels Good and One Direction's album entitled Midnight Memories. Based on the analysis above, there were five types of figurative language found in the song lyrics of 5 Seconds of Summer's album and four types of figurative language found in the song lyrics of One Direction's album as well.

Based on the analysis above, there were five types of figurative language found in the song lyrics of 5 Seconds of Summer's album, they are: personification (personification of an abstract idea are: I can't sleep 'cause my mind keeps racing, Voices coming through the speaker, The words you speak, surrounding me, The air you breathe is haunting me), irony (everybody's got their demons, Everyfire I've ignited faded to grey and A sinking ship I'll never save), simile (When I catch fire and watch over you like the sun, I want to feel your love like the weather, I wanna breathe you in like your vapor, I'm lonely like a castaway, I'm over off the small talk setting off like fire in the wind, It seems I just lost track looking on as all of life's colors seem to fade to grey), hyperbole (I wanna take my heart to the end of the world and Drove into infinity) and metaphor (I'm a broken stereo, out of time).

There were four types of figurative language found in the song lyrics of One Direction's album as well, they are: personification (personification of an abstract idea: lights go down and the night is calling to me, yeah. Personification of inanimate object: little black dress just walked into the room, and your eyes keep saying things), simile (but, baby, running after you is like chasing the clouds, my hands, your hands, tied up like two ships), hyperbole (light a fire inside those eyes) and metaphor (I'm half a heart without you).

Based on the analysis, there were two types of meaning found in this study, they are conceptual meaning and connotative meaning. From 5 Seconds of Summer's album, four sentences using connotative meaning (everybody's got their demons, Everyfire I've ignited faded to grey, I'm a broken stereo, out of time and A sinking ship I'll never save) and twelve sentences using conceptual meaning (I can't sleep 'cause my mind keeps racing, Voices coming through the speaker, The words you speak, surrounding me, The air you breathe is haunting me, When I catch fire and watch over you like the sun, I want to feel your love like the weather, I wanna breathe you in like your vapor, I'm lonely like a castaway, I'm over off the small talk setting off like fire in the wind, It seems I just lost track looking on as all of life's colors seem to fade to grey, I wanna take my heart to the end of the world and Drove into infinity). While from One Direction's album, two sentences using connotative meaning (light a fire inside those eyes and little black dress just walked into the room) and five sentences using conceptual meaning (lights go down and the night is calling to me, yeah, and your eyes keep saying things, but, baby, running after you is like chasing the clouds, my hands, your hands, tied up like two ships and I'm half a heart without you).

\section{References}


Crowley, Ashley. et al. (2000). AZLyrics. Available from: https://www.azlyrics.com/ [accessed 6 December 2017].

Kasper, G. and Kellerman, E. (1997). Communication Strategies: Psycholinguistic and Sociolinguistic Perspectives. London: Longman.

Keraf, Gorys. (2004). Diksidan Gaya Bahasa. Jakarta: PT GramediaPustakaUtama.

Knickerbocker, K.L and H. WilliardReninger. (1963). Interpreting Literature. Toronto: Holt, Rinehart and Winston, Inc.

Leech, G.N. (1974). Semantics. Aukland: Penguin Book.

Leech, G.N. (1983). Principles of Pragmatics. New York: Longman Singapore Publishing.

Morner, Katlhen and Ralph Rausch. (1991). NTC's Dictionary of Literary Terms. USA: NIC publishing group. 